\title{
Tentative Discussion of Global Financial Imbalance
}

\author{
Yong Zheng \\ Shandong University of Finance \\ 40 Shun Geng Road, Jinan 250014, China \\ Tel: 86-531-829-11079
}

\begin{abstract}
At present, the disorder change of the exchange rate, the interest rate rising have already posed the serious threat to the global economy continually growth. The global unbalance causes include the low American deposit level, the Chinese exchange rate lacking the elasticity, as well as Japanese, German and oil-producing country favorable balance. In order to solve this problem, the developed countries and the developing nations must joint effort to reduce the serious unbalance of the whole world day by day, and at the same time, change International Monetary Fund's role as the center of strengthening cooperation as well as resolving trade imbalance. And the international economy finance organization must increase the voting rights of the developing nations. Finally it pointed out that RMB revolution wasn't the effective method to solve the Chinese and American trade gap.
\end{abstract}

Keywords: International payment balance, Private capital, RMB exchange rate

\section{Introduction}

The recently published report of World Bank in the "Global Development Finance 2005" reveals that: net private capitals that flow into the developing countries in 2004 increased by 5.1 billion U.S. dollars to reach 301.3 billion U.S. dollars. Foreign Direct Investment (FDI) in net totaled 165.5 billion U.S. dollars in 2004 with an increase of 13.7 billion U.S. dollars. Developing countries continue to increase their own capital outflows, meantime, coordinate with strengthening the balance of their current account, so the total surplus of them in 2004 reached 124 billion U.S. dollars. Global economic growth reached $3.8 \%$ in 2004 , the fastest in the latest four years, and the developing countries achieved the fastest rate in the latest 30 years. And the growth rate of the region where the developing countries centralized is higher than the average level over the past 10 years. But at the same time, global imbalances are continuously expand, particularly the United States current account deficit reached 805 billion U.S. dollars in 2005. Therefore, Gains of the developing countries are vulnerable to the risks associated with the restructuring. Just as senior vice president of the World Bank, economists Ms. François Bourguignon said, "However, we should also keep in mind that the existent Global financial imbalances today have created risks -- disorderly fluctuate of the exchange rate, rise of the interest rates - these may pose a threat to our gains. Developing countries need to prepare themselves to do a good job of adjusting, and some adjustments could be paroxysmal".

\section{The performance of global financial imbalances}

Firstly, although the international trade in goods and services grew steadily, is also faced with the threat of global imbalances and uncertainty of the economic growth. World Trade Organization said in its annual report of the 2005 estimates that after adjustment for inflation, global trade in goods increased by $6 \%$, which is lower than expected of $9 \%$ in 2004, but higher than the average level over the past 10 years. European Union (EU) and Japan's exports dropped sharply, U.S. export growth has been slow as well, but China's actual exports which soared $25 \%$ will continue to grow, pushing up global export volume. Services trade of emerging economies, particular the "Golden Brick Four" (Brazil, Russia, India, China), has also grown substantially. However, the share of these countries in the global market is still relatively small.

Secondly, the current account deficit of the United States for 27 years has become the obstacle that affects the stability of the world economy. Every three containers that reach Long Beach, which is America's second largest port, will leave with two empty. Nothing could be better than this image shows a deficit of the United States as a threat to world economic stability. Beginning in 2006, the United States prepared to publish the current account deficit in 2005 (which includes trade in services. interest payments and transfer payments). This amount is about 805 billion U.S. dollars, which is equivalent to $6.5 \%$ of the gross domestic product (GDP), setting a record. Since 2002, the U.S. dollar has fallen more than $15 \%$ to the currencies of major trading partners of the United States. Some smaller Asian central banks hinted that they want to shift reserving a variety of foreign exchanges from simple dollars. However, few people expect 
the final result: because the relentless rise in oil prices push up import costs, the U.S. trade deficit get more serious; oil producers, has become the new creditors of global economy; Strong growth in the United States and the global economy has eliminated two tense situation, it's the ever-increasing debt which the United States owe the other countries of the world, and high energy prices as well; The falling trend of the dollar has therefore been reversed due to large capital inflows. From 1913-2001, the United States accumulated a total national debt of 6 trillion Yuan, and from 2001-2006, the United States national debt also increased by 3 trillion US dollars to 8.6 trillion US dollars in the short period of five years.

Thirdly, the United States current account deficit accounted for a record-high proportion of the national income, and the imbalances in global economic asymmetry is more obvious. The United States current account deficit accounts for high proportion of the total national income. The U.S. current account deficit seriously deteriorated in the fourth quarter of 2005 , the deficit represented the percentage of its national income to a record high of $7 \%$. In the fourth quarter of in 2005, the current account deficit of the United States is 225 billion U.S. dollars which is far higher than 185.4 billion U.S. dollars of the third quarter. The current account deficit of the third quarter accounts for a ratio of 5.9\% of the gross domestic product (GDP). And the current account deficit for the year 2005 is 805 billion U.S. dollars, accounting for $6.4 \%$ of national income. At present, the global financial imbalances continue to aggravate with an alarming rate. Meanwhile, a dangerous asymmetry emerges among the various imbalances. In the year of 2005, the current account deficit of the United States reached a record level, and accounted for about $70 \%$ of the total global economic deficit. According to IMF statistics, the United States current account deficit accounted for about 1.6\% of global GDP last year. Meanwhile, the surplus areas of the world include: the emerging Asian countries, its surplus accounted for $0.5 \%$ of global GDP; oil-exporting countries, $0.5 \%$ of global GDP; Japan, $0.4 \%$ of global GDP; and the euro zone, Denmark, Switzerland and Norway, also have a surplus of $0.4 \%$ of global GDP. On the other hand, the surplus areas should be spread in much more scope: $70 \%$ of the total global current account surplus in 2005 came from about 10 economies. Indeed, the world was maintaining the balance on the needle of the U.S. external imbalances. If the United States who has the world's largest deficit sinks deeper in the deficit problem, while major global surplus States absorb its own savings at the same time, then the United States will feel increasing pressure on external financing. This will undoubtedly increase the possibility that these pressures will have to release in the international financial markets by the classic way of adjusting the current account, which means that dollar is to weaken and interest rates is to rise in the United States. As long as other countries in the world are in a state of excess savings, it is possible to avoid a substantial re-pricing of dollar-denominated assets. But now, with the surplus economies embarking on the long road of self-absorption of excess savings, it will be more difficult for the United States to prevent such a dangerous outcome.

\section{Conclusions: Solutions of the global financial imbalances}

\subsection{Developed and developing countries should work together to reduce the growing problem of global imbalances}

The International Monetary Fund pointed out in its important magazine "World Economic Outlook" that rich countries and developing countries have failed to take the necessary steps to reduce growing global imbalances. The IMF has called on the United States to make efforts to increase national savings to reduce the deficit for long time. And at the same time, Europe and Japan should implement structural reforms to remove obstacles to the economic growth, and Asian countries should increase exchange rate flexibility to upgrade its domestic demand. Although every country has agreed to take necessary steps to reduce global imbalances, they are all relatively slow in the implementation. Raghuram Rajan, the IMF chief economist, said that the related countries should play their own role by taking action to establish a "mutually agreed, credible multilateral framework for policy action, to help maintain market remain stability." According to the IMF reports, the global economic growth rate of 2005 will reach $4.3 \%$, continuing to maintain a robust posture, but still "excessively depend on" the United States and China. The phenomena above makes people worry that there will be a marked slowdown in the global economy if the United States and China synchronously experienced weak economy. As said by Raghuram Rajan, "a large number of emerging markets, especially emerging Asian countries, have accumulated a huge amount of foreign exchange reserves to prevent the disaster from happening. However, the excessive accumulation of foreign exchange reserves will undermine the currency control, as well as the health of the financial system."

\subsection{Change the role of IMF as the center of strengthening cooperation as well as resolving trade imbalance}

As to global economic governance, leading countries generally believe that the role of the International Monetary Fund should be changed to place itself in the center of strengthening cooperation as well as resolving the trade imbalance. International Monetary Fund has been authorized to immediately launch the negotiations among the countries which have the largest trade imbalance amount. And the goal of the negotiations was to reach an agreement on reforming the economy and exchange rate policies, so as to narrow the trade balance and to prevent the occurrence of the global financial crisis. If the negotiations succeed, it will likely lead to major changes in economic policy, including the appreciation of the RMB. In the first IMF "multilateral consultation", the various causes of global imbalances which include the low level of savings in the United States, the inflexibility of exchange rate in China, as well as the surplus of 
Japan, Germany and oil-producing countries will become the focus of public attention. And IMF will serve as a forum for participating countries to seek solutions to these economic problems. According to IMF Managing Director Rodrigo Rato, because the IMF can not force countries to change its policy, it will announce results of the analysis to exert additional pressure to induce them to reach agreement. Including China, all IMF members support the new procedures. Meanwhile, IMF members reach a consensus that some emerging market countries should be given greater IMF quotas and voting rights.

3.3 Program of $G 11$ (including Group of Seven, China, India, Russia and Brazil), and consider increasing the voting rights of developing countries

Some of the world's largest banks and financial institutions urged in September 14, 2005 that global economic leaders should joint action to reduce the increasingly alarming global financial imbalances. And Institute of International Finance appealed that G7 which was constituted by leading industrial nations should incept China, India, Russia and Brazil as their members. The G11 which includes industrialized countries and emerging market countries may offer impetus to the economic reform which is necessary. And some of the economic reform has been mentioned but has not been fully implemented due to the absence of such an understanding that the parties need to take difficult compromise. In addition, Many Asian countries deem that they have still been marginalized in the multilateral organizations after years of rapid growth for a long period of time which was not fair. And it is generally felt that the organization preferred the relatively smaller European countries. However, other countries, particularly Turkey and Mexico, do not have enough say in the IMF. For example, Belgium has $2.16 \%$ of the voting rights in the IMF, compared with only $2.98 \%$ of China. Despite the scale of China's economy is six times larger than that of Belgium measuring with the nominal gross domestic product (GDP); but by purchasing power parity (PPP) measurement, the Chinese economy is more than 20 times larger than that of Belgium.

\section{References}

Krishna, Guha. (2006). Consultations between the IMF and strong countries to settle global imbalances. Britain's "Financial Times" (April 19, 2006).

Javier, Blas. (2006). IMF: High oil prices will exacerbate global imbalances. Britain's "Financial Times" (April 7 , 2006).

Krishna, Guha. \& Scheherazade, Daneshkhu. (2006). IMF: dollar must depreciate substantially. Britain's "Financial Times" (April 20, 2006).

Chris, Giles. \& Krishna, Guha. (2006). IMF will immediately start negotiations on global imbalances. Britain's "Financial Times" (April 24, 2006). 